Gabriel, M. W., L. V. Diller, J. P. Dumbacher, G. M. Wengert, J. M. Higley, R. H. Poppenga, and S. Mendia. 2018. Exposure to rodenticides in Northern Spotted and Barred Owls on remote forest lands in northwestern California: evidence of food web contamination. Avian Conservation and Ecology 13(1):2. https://doi.org/10.5751/ACE-01134-130102

Copyright (C) 2018 by the author(s). Published here under license by the Resilience Alliance.

Research Paper

\title{
Exposure to rodenticides in Northern Spotted and Barred Owls on remote forest lands in northwestern California: evidence of food web contamination
}

\author{
Mourad W. Gabriel ${ }^{1,2}$, Lowell V. Diller ${ }^{3}$, John P. Dumbacher ${ }^{4}$, Greta M. Wengert ${ }^{5}$, John M. Higley ${ }^{6}$, Robert H. Poppenga ${ }^{7}$ \\ and Shannon Mendia ${ }^{6,8}$ \\ ${ }^{1}$ Integral Ecology Research Center, ${ }^{2}$ University of California Davis Karen C. Drayer Wildlife Health Center-One Health Institute, \\ ${ }^{3}$ Green Diamond Resource Company, ${ }^{4}$ California Academy of Sciences, Ornithology and Mammalogy Department, ${ }^{5}$ Intergral \\ Ecology Research Center, ${ }^{6}$ Hoopa Tribal Forestry, Wildlife Department, ${ }^{7}$ California Animal Health and Food Safety Laboratory, \\ University of California Davis, ${ }^{8}$ Humboldt State University
}

\begin{abstract}
The documentation of anticoagulant rodenticides (AR) in nontarget species has centered around wildlife that inhabit urban or agricultural settings. However, recent studies in California have shown that AR use in remote forest settings has escalated and has exposed and killed forest carnivores. Anticoagulant rodenticides have been documented as physiological stressors for avian species. Northern Spotted Owl (Strix occidentalis caurina) critical and occupied habitat overlaps the areas where these studies occurred, yet no data were previously available to demonstrate whether this species was similarly affected. We investigated whether avian predators are also exposed to these specific pesticides and whether Barred Owls (Strix varia) may be a surrogate to indicate exposure rates in Northern Spotted Owls. We documented that $70 \%$ of Northern Spotted Owls and $40 \%$ of Barred Owls were exposed to one or more anticoagulant rodenticides. None of the rodent prey species sampled within the study area were positive for ARs. There were no spatial clusters for either low or high rates of exposure, though we detected low temporal trend early on throughout the study area. We hypothesize a recent change in land-use toward marijuana cultivation may have led to the increased use of AR in this area. This study demonstrates environmental contamination within occupied Northern Spotted Owl habitat and that Barred Owls can be used as adequate surrogates for detecting these pollutants in a rare species such as the Northern Spotted Owl. Furthermore, additional studies should focus on whether these pesticides are also affecting prey availability for these forest avian species.
\end{abstract}

\section{Exposition aux rodenticides chez les Chouettes tachetée du Nord et rayée dans les terres forestières éloignées du nord-ouest de la Californie : indice de contamination du réseau alimentaire}

RÉSUMÉ. Les cas d'exposition à des rodenticides anticoagulants (RA) chez les espèces non ciblées ont surtout été documentés pour la faune habitant les milieux urbains ou agricoles. Toutefois, de récentes études en Californie ont montré que l'utilisation de RA dans les environnements forestiers éloignés a grimpé, et des carnivores forestiers y ont été exposés et en sont morts. On a aussi documenté que les RA sont des facteurs de stress physiologique pour les espèces aviaires. L'habitat critique occupé par la Chouette tachetée du Nord (Strix occidentalis caurina) chevauche les endroits où ces études ont eu lieu, mais aucune donnée n'était auparavant disponible pour déterminer si cette espèce était aussi touchée. Nous avons examiné la possibilité que les prédateurs aviaires soient aussi exposés à ces pesticides spécifiques, et si les Chouettes rayées (Strix varia) pouvaient servir d'indicateur pour les taux d'exposition des Chouettes tachetées du Nord. Nous avons quantifié que $70 \%$ des Chouettes tachetées du Nord et $40 \%$ des Chouettes rayées étaient exposées à au moins un RA. Aucune des espèces proies de rongeurs échantillonnées dans notre aire d'étude ne se sont révélées positives pour les RA. Nous n'avons pas observé d'agrégations spatiales de bas taux d'exposition ou de taux élevés, bien que nous ayons détecté une tendance temporelle faible au début de notre investigation dans l'aire d'étude. Nous pensons qu'un changement récent de l'utilisation des terres vers la culture de la marijuana pourrait avoir engendré une augmentation de l'utilisation de RA dans cette région. Nos résultats indiquent que l'environnement est contaminé dans l'habitat occupé par la Chouette tachetée du Nord, et que la Chouette rayée peut servir d'indicateur pour qu'on puisse détecter ces polluants chez une espèce rare telle que la Chouette tachetée du Nord. De plus, les recherches futures devraient se pencher sur la possibilité que ces pesticides affectent aussi la disponibilité des proies pour ces espèces aviaires forestières.

Key Words: anticoagulant rodenticides; cannabis; ecotoxicology; environmental contamination; forest toxicology; invasive species; marijuana; poison; prey; raptor; rodent 


\section{INTRODUCTION}

The negative effects of anticoagulant rodenticide (AR) on nontarget wildlife have been well documented worldwide (Eason et al. 2002, Erickson and Urban 2004). The bulk of these studies are accounts within urban, peri-urban, and agricultural habitat settings where wildlife are the most likely nontarget groups to be exposed to or poisoned by these compounds. However, emerging use of AR in remote forest settings has recently been documented in the western United States (Gabriel et al. 2012, 2015). The widespread use of AR at illegal clandestine marijuana cultivation sites on public and tribal lands has been a significant source of wildlife exposures in these California habitats (Gabriel et al. 2012, Thompson et al. 2014). Concurrently, accumulating data have demonstrated deleterious impacts from ARs for a rare forestdwelling carnivore in California, the fisher (Pekania pennanti), as indicated by exposure rates, population survival trends, and direct cause of mortality (Gabriel et al. 2012, 2015, Thompson et al. 2014). In California and other western states, fishers inhabit remote forests and require deteriorating mature and old-growth forested habitat structures for offspring rearing. The fisher has now been established as a sentinel of AR exposure risks to others terrestrial forest wildlife that is of conservation concern (Gabriel et al. 2012, 2015).

The level of AR contamination in avian wildlife within fisheroccupied remote forested lands has not been assessed to date. One such species of vital conservation importance is the Northern Spotted Owl (NSO; Strix occidentalis caurina). The NSO is a federally listed species in the United States under the Federal Endangered Species Act (ESA) and was recently listed as threatened under the California Endangered Species Act. Its current and historical range and designated critical habitat overlap considerably with fishers as well as marijuana cultivation (Gabriel et al. 2013). Initially, one of the main factors of the precipitous population decline for NSO was the loss of and modification of its habitat (United States Fish and Wildlife Service 2011). These factors have led to countless biologists working for over 30 years toward restoring this species' viability. However, over the course of several decades, the Barred Owl (BO; Strix varia) has expanded from its historical range in eastern North America to its current range including the Western United States (Gutiérrez et al. 2007). Barred Owls now overlap ESA critical habitat designated for NSO and competes with NSO for natural resources that facilitate successful breeding, feeding, and sheltering for the species (United States Fish and Wildlife Service 2011, Wiens et al. 2014, Diller et al. 2016, Dugger et al. 2016).

Unfortunately, illegal clandestine marijuana cultivation complexes have been occurring on private, tribal, and public lands, are increasing throughout California and the Pacific Northwest (Corva 2014, Butsic and Brenner 2016), and often fall within NSO-designated ESA critical habitat and occupied NSO and BO territories (Gabriel et al. 2013). The use of ARs at these sites may adversely affect NSOs and recently, in their final status review report to the California Fish and Game Commission regarding the conservation status and threats to NSO, the California Department of Fish and Wildlife stated that toxicants such as ARs from marijuana cultivation sites likely pose "a serious and widespread threat to northern Spotted Owls" (Battistone and Clipperton 2016:178; Long et al. 2014).
Recently, an experimental wildlife management program has been initiated in California where BO have been lethally removed because of interference competition with NSOs and to monitor their responses to the potential release of resources sequestered by BO (Gutiérrez et al. 2007, Diller et al. 2014). Typically, collection of tissues of nonmonitored wildlife populations is restricted to sick, dying, or dead animals discovered haphazardly in the field or near areas where the likelihood of human discovery is high (Wobeser 2006, 2007). These removal efforts provide a rare opportunity to collect owl tissues in quantities not normally available, and that would typically take many years to accumulate. Thus, this program provides an opportunity to collect biological samples that more accurately reflect the natural $\mathrm{BO}$ population exposure.

Because BO are congeners of NSO and ecologically similar (Gutiérrez et al. 2007, Wiens et al. 2014), we investigated BO exposure to ARs. We also investigated if $\mathrm{BO}$ can be relevant proxies for NSO exposure, even though there are some differences in their diet. We investigated if $\mathrm{BO}$ exposure to AR can be used as an indicator for habitat-wide exposure, and examined whether there are any temporal, seasonal, sex, age classes, or behavioral (colonizer vs. resident) differences among AR exposed owls sampled. For example, we examined whether spatial pattern of AR exposure were clustered or ubiquitous within the landscape such that source points might be determined and focused conservation measures developed.

We investigated opportunistically collected NSO within or near the $\mathrm{BO}$ project area to test if there were differences in exposure rates between the two species and determine if $\mathrm{BO}$ can be used as surrogates for NSOs. Rodents compose the main diet for NSO as well as BOs (Hamm and Diller 2009, Wiens et al. 2014). We sampled opportunistically collected rodents within the project area to investigate whether these prey are exposed to ARs and if AR-positive rodents are associated with positive owls. Finally, we anticipated that any data generated from these investigations would assist natural resource agencies, researchers, and scientists to investigate whether other species, avian or terrestrial, that use the same prey base as BO or NSO are similarly at risk from AR threats.

\section{METHODS}

\section{Study area}

The study area for BO collections was on Green Diamond Resource Company (GDRC) privately held, commercially managed timberlands in northwestern California within the counties of Del Norte and Humboldt (Figs. 1 and 2). These timberlands are large tracts that have restricted access and are bordered by public, tribal, and other private land. These timberlands contain both second- and third-growth conifer and hardwood forests on a 50- to 60-year rotation (Hamm and Diller 2009, Diller et al. 2014). Habitat characteristics consist of both conifer and hardwood forests, with coast redwood (Sequoia sempervirens), Douglas-fir (Pseudotsuga menziesii), and interspersed tanoak (Notholithocarpus densiflorus), madrone (Arbutusmenziesii), California bay (Umbellularia californica), and red alder (Alnus rubra; Hamm and Diller 2009, Diller et al. 2014). 
Fig. 1. Collection locations for Northern Spotted Owls (NSO; Strix occidentalis caurina), Barred Owls (BO; Strix varia), and rodents and their anticoagulant rodenticide (AR) status in Northwestern California, USA. Positive NSO and BO are represented by yellow and red circles, respectively. The northern study area in Del Norte County and the southern study area in Humboldt County are delineated by dashed county lines.

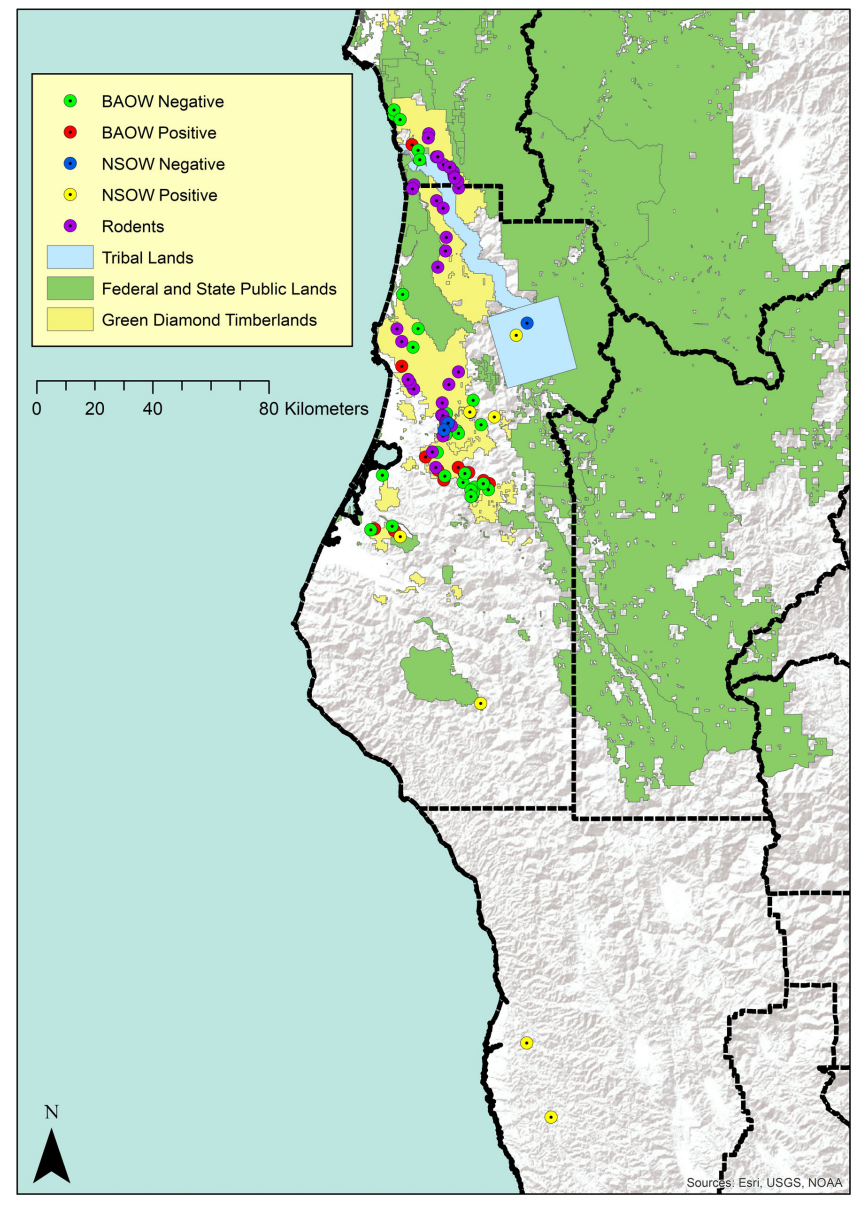

\section{Tissue collection}

All BO tissue samples for this study were provided for laboratory analysis from principal investigators conducting lethal BO removal projects on GDRC lands. Barred owls were killed with a 12- or 20-gauge shotgun following Diller et al. (2014) protocols and methods. All animals were collected under the following state and federal permits, United States Fish and Wildlife permit numbers MB103642-0, MB 680765-1, MB 17356A-0, and California Department of Fish and Game scientific collection permit numbers SC-801126-05 and SC-000687. Owls were then submitted to the California Academy of Sciences, San Francisco, CA, where in addition to the collection of other ancillary data and museum preparations, a portion of the liver (1-3 grams) was collected for AR testing. We collected data on sex and age classes, behavior (colonizer vs. resident), and collection locality. Barred Owl sites with one or more years of historical reoccurring Barred
Owl occupancy were considered "resident" individuals. Resident designated owls were not marked and subsequently it would be difficult to know how long an owl may have been on site prior to collection. However, owls collected at these sites were currently and historically occupied by BO. In contrast, if surveys with or without lethal removal indicated a site was not occupied by $\mathrm{BO}$ historically or in the previous year, the owl was designated a "colonizer" based on the assumption that it had colonized the site within the last year.

Fig. 2. Collection locations for Barred Owls (BO; Strix varia), and rodents and their anticoagulant rodenticide (AR) status on Green Diamond private timberlands in Northwestern California, USA. Positive BO are represented by yellow circles, respectively. The northern study area in Del Norte County and the southern study area in Humboldt County are delineated by dashed county lines.

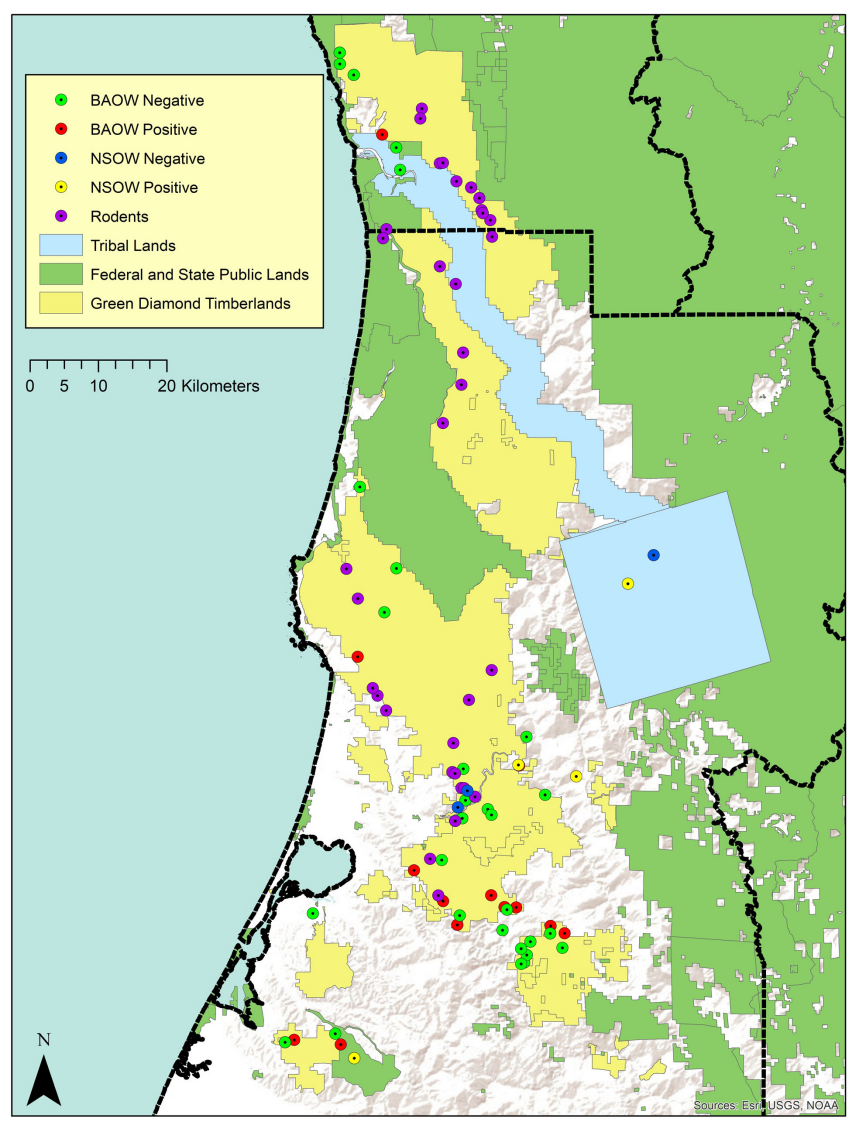

All NSO carcasses were opportunistically collected when they were found dead in the field where other research or management activities were occurring by either a private company or federal agency biologists and submitted to either the United States Fish and Wildlife Service field office in Arcata, California or Humboldt State University Wildlife Museum in Arcata, California. If the carcass was in fair to good postmortem condition, it was then submitted for a necropsy by a boardcertified wildlife pathologist at the California Animal Health and Food Safety Laboratory System (CAHFS) on the campus of the University of California at Davis, California, USA. If an NSO 
Table 1. Results of Northern Spotted Owls (Strix occidentalis caurina) anticoagulant rodenticide exposure, cause of death, location of collection, year and season of collection, and the sex of the individual from both Humboldt and Mendocino Counties in Northwestern California, USA.

\begin{tabular}{|c|c|c|c|c|c|c|}
\hline Owl & Cause of Death & $\begin{array}{c}\text { Land } \\
\text { Ownership }\end{array}$ & Year Collected & Season & Sex & AR Status \\
\hline 001 & Road Kill & Highway & 2012 & Spring & Adult Female & Brodifacoum \\
\hline 002 & Unknown & Private & 2012 & Summer & Adult Female & $\begin{array}{l}\text { Brodifacoum, } \\
\text { Bromadiolone }\end{array}$ \\
\hline 003 & Emaciation/Disease & Private & 2013 & Summer & Juvenile Male & Negative \\
\hline 004 & Emaciation/Disease & Private & 2013 & Fall & Adult Female & Negative \\
\hline 005 & Road Kill & Tribal & 2014 & Fall & Subadult. Male & Brodifacoum \\
\hline 006 & Unknown & Private & 2015 & Summer & Adult Female & Brodifacoum \\
\hline 007 & Unknown & Private & 2015 & Fall & Adult Female & $\begin{array}{l}\text { Brodifacoum, } \\
\text { Bromadiolone }\end{array}$ \\
\hline 008 & Unknown & Tribal & 2015 & Winter & Adult Female & Negative \\
\hline 009 & Road Kill & Highway & 2015 & Fall & Adult & Brodifacoum \\
\hline 010 & Predation & Private & 2016 & Fall & Adult Male & Brodifacoum \\
\hline
\end{tabular}

carcass was too far degraded for a full necropsy, only liver (1-3 grams) tissue then was provided for testing. Only NSO that were collected within or near the GDRC BO collection sites in Northwestern California, which included southern Del Norte, western Trinity, Humboldt, or northern Mendocino Counties were tested. We did not receive or test any NSO tissue from other portions of their range, e.g., Oregon or Washington State. Sex, age class, collection location, and cause of mortality were provided or determined via necropsy at CAHFS for each NSO carcass or tissue submission.

Rodent samples were opportunistically collected from researchers as trap mortalities during a nonrelated field project focusing on vector-borne pathogens within the $\mathrm{BO}$ removal project area on GDRC lands (Figs. 1 and 2; Dr. Janet Foley, the University of California at Davis, personal communication). Liver samples were obtained and submitted to CAHFS for AR analysis. Each animal collected had their species, sex, and collection location recorded.

\section{Tissue testing}

Livers were screened at CAHFS Laboratory for eight ARs including first-generation ARs, warfarin (WAF), diphacinone (DIP), chlorophacinone (CHL), and coumachlor (COM) and including second-generation ARs, brodifacoum (BRD), bromadiolone (BRM), difethialone (DIF), and difenacoum (DIC) by liquid chromatography-tandem mass spectrometry. All detected ARs were quantitated by high-performance liquid chromatography. The reporting limits were $50 \mathrm{ppb}$ for BRD, 20 ppb for all other ARs. If a liver was positive, but the AR was below a quantifiable level, it was designated as "trace" detection.

\section{Spatial and temporal scan statistics}

We used the spatial scan statistical software SaTScan version 9.4.4 (M. Kulldorff, Harvard Medical School, Boston, MA, USA) and a Bernoulli model with case (positive AR) and noncase (negative AR) data to determine if spatial clustering occurred in $\mathrm{BO}$ samples as previously described (Gabriel et al. 2012). This model allowed us to investigate whether clustering occurred either temporally, spatially, or relative to a combination of both time and space, as well as distinguish whether one or more statistically significant clusters occurred throughout the full study area. Temporally, the model investigated any trends within an individual year or groups of years. Spatially, the elliptical scanning window option was used with both circular and elliptical shapes to allow for a better fit to linear geographic features. All statistical values from the models were generated by Monte Carlo simulations of 999 iterations and clusters evaluated for significance with alpha $=0.05$. Model runs were conducted for the complete $\mathrm{BO}$ data set and then separated for the two collection regions, with the north set having all Del Norte County BO samples and the south set having all owls in Humboldt County. We separated these two regions because of current and historical law enforcement data on greater densities of both private and public land marijuana cultivation sites in Humboldt compared to Del Norte County. This difference between the two counties likely reflects climatic differences between these two areas where the north set is less conducive to marijuana cultivation, compared to the south set. Spatial Scan Results were viewed and confirmed with ESRI ArcMAP 10.1 (ESRI, Redlands, California, USA).

\section{RESULTS}

\section{Northern Spotted Owls exposure}

We tested 10 NSO livers for AR. Of these, three were male, six were female, and the sex for one owl could not be determined because of the poor condition of the carcass. Seven out of 10 $(70 \%)$ livers from NSO were positive for one or more AR. All seven livers had the second generation rodenticide BRD detected with two owls having both BRD and second generation BRM present. All AR compounds were detected at trace levels. Of the positive owls, two were males, four were females, and the sex of one owl was unknown. Dates and seasons for NSO collection varied (Table 1). The primary cause of death was determined for 6 of the 10 NSOs. Three owls were killed by vehicular strikes and two owl deaths were attributed to emaciation accompanied by an undetermined infectious etiology. The final owl was killed by an unknown predator. Specific locations for the owls were provided by field personnel (Figs. 1 and 2).

\section{Barred Owl exposure}

We tested $84 \mathrm{BO}$ liver samples for the presence of AR. The number of samples we collected each year varied (Table 2). Of these owls, $40(48 \%)$ were female, $40(48 \%)$ were male, and four owls $(5 \%$ : Unknown) did not have their sex recorded at the time of sampling. 
When combined across years, the samples we received represented owls collected in all four seasons (Fig. 3). Of the 84 owls, $48(57 \%)$ were deemed to be colonizers, 31 (37\%) residents, and the territory status of five $(6 \%)$ could not be determined.

Table 2. Results of Barred Owls (Strix varia) anticoagulant rodenticide exposure, year collected, and the sex of the individual from both Humboldt and Del Norte Counties in Northwestern California, USA.

\begin{tabular}{lccc}
\hline \hline Year & $\begin{array}{c}\text { Number of Owls } \\
\text { Collected }\end{array}$ & $\begin{array}{c}\text { Sex } \\
\text { (Male:Female) }\end{array}$ & $\begin{array}{c}\text { Anticoagulant } \\
\text { Rodenticide Positive } \\
\text { Owls }\end{array}$ \\
\hline 2006 & 9 & $5: 3,1$ Unknown & $5(56 \%)$ \\
2009 & 18 & $9: 9$ & $5(28 \%)$ \\
2010 & 14 & $7: 6,1$ Unknown & $5(36 \%)$ \\
2011 & 18 & $10: 8$ & $6(33 \%)$ \\
2012 & 24 & $10: 14$ & $12(50 \%)$ \\
2013 & 1 & $1: 0$ & $1(100 \%)$ \\
Total & 84 & $42: 40,2$ Unknown & $34(40 \%)$ \\
\hline
\end{tabular}

Fig. 3. Percent of all Barred Owls (Strix varia) positive for exposure to anticoagulant rodenticides during each season collected from Humboldt and Del Norte Counties during the years of 2006-2013 in Northwestern California, USA.

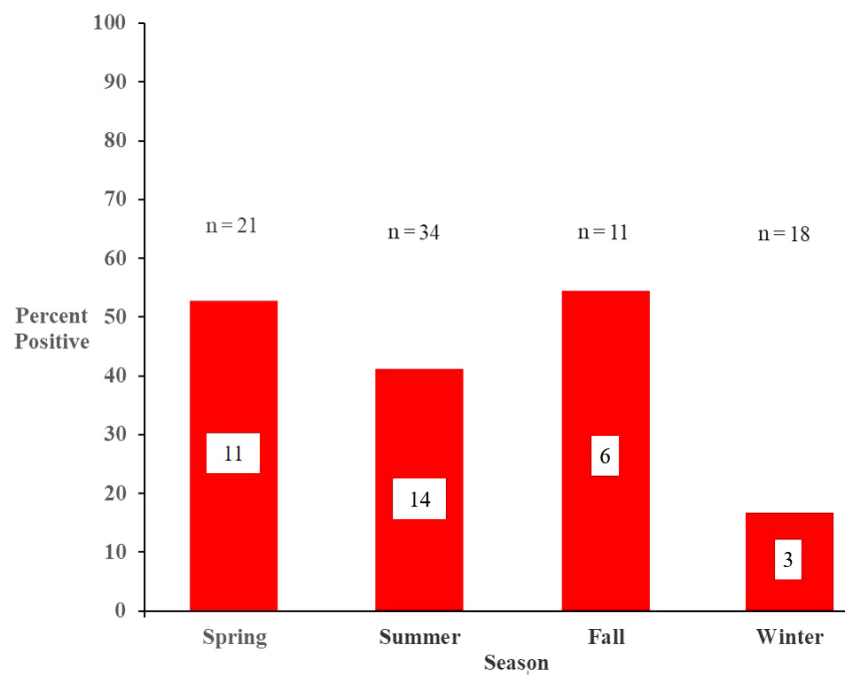

We detected exposure to one or more AR compound in $34(40 \%)$ BO. Thirty of these $34(88 \%)$ owls had a single AR present in their tissue (BRD: 27; BRM 3), while four owls (12\%) had two different types of AR present (BRD and BRM). All BRM detections were at a trace level while six of the $31 \mathrm{BRD}$ detections had quantifiable levels $($ mean $=0.056 \mathrm{ppm}$; range $0.017-0.11 \mathrm{ppm})$. There were no differences in exposure between the sexes $\left(x^{2}=1.88 ; \mathrm{p}=0.17\right.$; $\mathrm{df}$ $=1$ ), where 14 males and 20 females were positive. Of the positive owls, $22(65 \%)$ were colonizers, $10(35 \%)$ were residents, and two were of unknown resident status. There were no differences in colonizing or resident owls for AR exposure $\left(x^{2}=1.4 ; \mathrm{p}=0.23\right.$; $\mathrm{df}=1)$, number of ARs detected $\left(x^{2}=0.36 ; \mathrm{p}=0.55\right.$; $\left.\mathrm{df}=1\right)$, or specific type of $\operatorname{AR}\left(x^{2}=0.37 ; \mathrm{p}=0.55 ; \mathrm{df}=1\right)$.

\section{Rodents}

We opportunistically collected a total of 36 rodent livers from GDRC lands between September 2011 and November 2011 with one rodent collected in February of 2012 (Figs. 1 and 2). Sexes and species collected varied, but Douglas squirrels, Tamiasciurus douglasii ( $\mathrm{n}=18: \mathrm{M}$ [9], $\mathrm{F}$ [9]) were the most abundant species, followed by chipmunks, Tamias sp. ( $\mathrm{n}=15$ :M [7], F [8]), northern flying squirrels, Glaucomys sabrinus ( $\mathrm{n}=2: \mathrm{M}[0], \mathrm{F}[2])$, and duskyfooted woodrats, Neotoma fuscipes $(\mathrm{n}=2: \mathrm{M}$ [0], F [2]). All rodent livers were negative for ARs.

\section{Spatial and temporal scan statistics}

There were no significant temporal trends or spatial patterns of positive $\mathrm{BO}(\mathrm{p}=0.29)$. When we investigated regional differences in ARs detected in owls collected in the north (Del Norte) vs. the south (Humboldt), we observed significantly fewer AR-positive owls than predicted in the south during 2009-2011 $(\mathrm{p}=0.04, \mathrm{n}=$ 41). The model predicted that there would be 17 AR-positive owls during this time span but only 12 owls were positive within this period. No other significant findings were detected for either area spatially or temporally. There were no significant spatial or temporal trends for owls exposed to only BRD or BRM or both combined $(p=0.28)$.

\section{DISCUSSION}

This is the first published documentation of AR in NSO in addition to BO populations within the range of the Northern Spotted Owl. Anticoagulant rodenticides were detected in $70 \%$ of the NSO and $40 \%$ of the BO we sampled, and all positive owls were exposed to second generation AR. Our documentation of high AR exposure rates in owls that inhabit remote forests of northern California correspondingly confirms that both NSO and $\mathrm{BO}$ are exposed to AR by contaminated prey based on their diet compositions. In addition, $\mathrm{BO}$ can serve as a competent surrogate species for measuring environmental contamination within areas they coinhabit with NSO and that environmental contamination was relatively uniform and likely widespread.

\section{Exposure to AR}

Our findings that a high percentage of the BO (40\%) and NSO $(70 \%)$ we tested were exposed to AR is of significant concern because all of these owls were collected in remote forested lands with no nearby urban or peri-urban settings. Furthermore, the use of second generation AR in agricultural settings without human dwellings is not legally permitted and private timberlands like GDRC where samples were collected, cannot legally use any types of second generation ARs. Other studies have documented BO exposed to ARs; however, most of these studies were focused in their eastern range and within moderate to intensive urban agricultural settings (Albert et al. 2010, Murray 2011, Thomas et al. 2011). For example, Albert et al. (2010) documented that of the $92 \%$ of exposed BO, the majority of them were submitted from high agricultural use areas, e.g., poultry farms, where significant amounts of AR were likely used to deter infrastructure damage caused by rodent pests in these settings. However, no studies to date had focused on $\mathrm{BO}$ in remote nonurban or nonagricultural forest settings.

As for AR exposure data for Northern Spotted Owls or even their neighboring subspecies, the California Spotted Owl (Strix 
occidentalis occidentalis), data are lacking in both published and gray literature with the exception of one description in an internal report (MRC 2004). However, drawing from this study's data and recent data on northern California fishers (Gabriel et al. 2015), the AR concern within NSO habitat is clearly warranted. The occurrence of AR in both northern and California Spotted Owl habitats has been labeled as an ecological stressor and a significant emerging threat to both species (MRC 2004, Long et al. 2014).

\section{Sources of AR exposure}

It is unknown if point sources of exposure originate from a legal or illegal use of AR outside these private timber boundaries. Many of these owls may have inhabited lands that were adjacent to both Redwood National Park and Prairie Creek Redwoods State Park (Figs. 1 and 2), neither of which use ARs on the lands they manage for the public. In addition, pesticide use for the years of 2009 to 2013 for both Del Norte and Humboldt Counties (http://www. cdpr.ca.gov/docs/pur/purmain.htm) was only 0.90 kilograms of brodifacoum and 0.54 kilograms of bromodiolone. Allowable uses include agriculture, landscape maintenance, public health protection, structural protection, and vertebrate control. This is significantly less than what more densely populated California counties use in a single year (e.g., San Diego county, year 2012, BRD: 0.95 kilograms; BRM: 2.94 kilograms). Unfortunately, the database excludes amounts of BRD or BRM used around personal home and gardens, so the overall use for these counties could potentially be higher. Nevertheless, the use of second generation AR is not legally permitted in the habitats from which samples were collected for this study.

Our data confirm previously reported exposures in remote forest wildlife where both Northern California and Southern Sierra Nevada populations of fishers have been exposed to ARs at high prevalence (85\% of all fishers tested; Gabriel et al. 2012, 2015, Thompson et al. 2014). For fishers, AR exposure occurs through the thousands of illegal clandestine marijuana cultivation sites throughout their range on public and tribal lands (Thompson et al. 2014, Gabriel et al. 2015). The use of not only the ARs brodifacoum or bromadiolone, but other first and second generation ARs, in addition to neurotoxicant rodenticides like bromethalin, have been documented in large quantities (10-90 lbs. per cultivation site) at numerous illegal marijuana cultivation sites where these owls were collected (MRC 2004, Gabriel et al. 2012, 2013; Gabriel, unpublished data). Occurrence of marijuana cultivation sites on GDRC lands is nominal, and between 2012 and 2017 there have been no more than four sites detected and eradicated during this period (Gabriel, unpublished data). We suspect these low numbers are on account of the restrictive property access by locked gates to GDRC lands.

Land use changes as a result of the "quasi-legal" status for marijuana cultivation and lack of uniform environmental enforcement in California has also resulted in an upsurge of land being converted for this industry (Polson 2013, Butsic and Brenner 2016, Gianotti et al. 2017). A recent study using Google imagery estimated over 4400 individual private noncommercial timberland marijuana cultivation sites were present in Humboldt County alone (Butsic and Brenner 2016). Many of these private sites are illegal, unpermitted, have no human dwellings, nor are used for livestock production, therefore no AR may be legally used at these locations (Butsic and Brenner 2016, Gianotti et al.
2017). However, the use of ARs on permitted or illegal private marijuana cultivation sites has been documented (Gabriel, unpublished data). Unfortunately, the quantification or level of use of AR at these private noncommercial timberland marijuana cultivation sites is unknown at this time. In addition, a recent study by Wang et al. (2017) demonstrated that in comparison to commercial timber harvest practices in northwestern California, private marijuana cultivation generated proportionately greater increases in forest edge. This increase in forest edge from these sites could serve as foraging habitat for both species of owls.

\section{Prey resource contamination}

The two primary pathways for AR exposure are either primary exposure, where the individual is directly exposed to the toxicant from consuming bait, or secondary exposure by consuming ARcontaminated prey. The main source of exposure for these owls is through secondary exposure. Though we did not detect AR in any rodent species for this study, this is not unexpected because ARs, especially second generation ARs, which we detected in our owl samples, are acutely toxic and kill exposed rodents in a matter of days (Erickson and Urban 2004).

Based on numerous diet studies, rodents and lagomorphs compose $81-96 \%$ of an NSO diet, where the majority of the remaining percentage is birds, and $<2 \%$ is insects (United States Fish and Wildlife Service 2011, Wiens et al. 2014). Although BO are also predominantly consumers of mammal species $(60-70 \%$ rodents and lagomorphs), their diets include a higher portion of birds and insects as well as amphibians, fish, reptiles, snails, and crayfish. Previous studies have detected AR in insects, reptiles, fish, and mollusk species, but many of these accounts stem from experimental toxicity studies or were part of monitoring efforts after accidental AR discharge or intensive AR application for eradication of invasive species (Eason and Spurr 1995, Primus et al. 2005, Rueda et al. 2005, Weltje et al. 2013, Weir et al. 2015).

The wider diversity of prey for BO may serve as a dilution of AR exposure risks as suggested by the lower exposure levels in $\mathrm{BO}$ $(40 \%)$ compared to NSO $(70 \%)$. However, we do not know if nonmammal prey groups were contributing to BO exposure levels for this study, and whether the disparity between BO and NSO AR exposure levels was due to either prey diversity or NSO sample sizes. It should be noted that rodents may be exposed to AR via contaminated prey items such as insects, mollusks, reptiles, and amphibians. Therefore tertiary poisoning may be occurring in some instances.

\section{Spatial or temporal trends}

It is not surprising that we detected no spatial trends for either exposed or nonexposed categories. These spatial results are similar to a previous study investigating AR exposures for fishers near this study (Gabriel et al. 2012). The fisher study suggested AR contamination is likely widespread throughout its range because of the widespread occurrence of trespass marijuana cultivation sites (Gabriel et al. 2012). In addition, many of the BO were colonizers, which may suggest that source points of exposure could have originated well beyond their collection point. Therefore, if the AR sources for owls are the same source of exposure for fishers, environmental contamination may be ubiquitous throughout their territories, or perhaps the northern California occupied range. 
The temporal trend of fewer detected cases in comparison to expected in the initial years (2009-2011) and within the southern portion of the study cannot be fully explained at this time. One hypothesis is that this region recently underwent a significant change where more private nontimber industry land was converted from timber production to marijuana production (Butsic and Brenner 2016, Gianotti et al. 2017). This rapid and recent land use transformation and subsequent potential AR use may have resulted in the model expecting equal levels of positive owls during these years when compared to the later years for the study (2012-2013). Another hypothesis is that environmental contamination may have been present when collection of owls began but unlike fishers that are omnivorous, strict carnivores like owls may show a lag in exposures due to the delayed time it takes for bioaccumulation of AR at higher trophic levels (Walker et al. 2012).

\section{Sublethal effects}

Effects of sublethal doses of AR exposure are not well known in NSO, BO, or many other raptor species. Some published accounts have demonstrated sublethal AR exposure either decreases fitness or increases mortality from what would normally be considered a benign injury (Stone et al. 1999, Eason et al. 2002, Erickson and Urban 2004, Thomas et al. 2011). These include, reduced clutch size, brood size, fledging success, slower clotting time, and AR residual transfer to eggs (Erickson and Urban 2004, Rattner et al. 2012, Salim et al. 2014).

Northern Spotted Owls are currently declining in both their range and populations and growing evidence indicates the primary factor is the recent expansion of BO to western North America (Gutiérrez et al. 2007, Diller et al. 2014, Wiens et al. 2014). Competitive interactions between NSOs and BO and the ubiquitous grow sites in California forested lands might lead to the higher likelihood of exposure for NSO by either visiting more AR source points because of an increase in home ranges, in addition, the stress of these interactions may exacerbate underlying sublethal effects (Wiens et al. 2014, Battistone and Clipperton 2016).

Our results indicate that environmental contamination is occurring within NSO habitat and when coupled with ongoing competitive interactions and stress from concurrent $\mathrm{BO}$ occupation, pose as an additional ecological stressor. In addition, the route of exposure for both NSO and BO is through prey contamination via secondary poisoning by ARs applied at illegal clandestine marijuana cultivation sites. Our study further supports previous accounts that ARs are contaminating the food web within this region of northwestern California through these source points and that $\mathrm{BO}$ can be used as potential sentinels for AR environmental threats to NSO. However, NSOs may have higher exposure than $\mathrm{BO}$ on account of ecological differences as previously explained. Future research should focus on the demographic impacts to individual NSO pairs occupying territories that contain cultivation sites or have them nearby, in addition to the level of exposure and impacts from AR to prey populations, rodents, lagomorphs, and other prey groups within NSO critical habitat.

Responses to this article can be read online at: http://www.ace-eco.org/issues/responses.php/1134

\section{Acknowledgments:}

All of us would like to first and foremost acknowledge Lowell Diller who unexpectedly passed away during the final revisions of this manuscript. Lowell was a distinguished herpetologist, mammologist, and owl ecologist for the Pacific Northwest. To many his vigor of life clearly splilled over to all of those he mentored and taught. This manuscript is dedicated in his memory. We would like to thank the United States Fish and Wildlife Service, Arcata Field Office for providing the funding and support for this project via grant award \#F11 AP00371, and Ray Bosch from USFWS for managing the award. We would also like to thank the Green Diamond Resource Company, California Academy of Sciences, Mendocino Redwood Company, Humboldt Redwood Company, Humboldt State University Wildlife Museum, Humboldt Wildlife Care Center, Dr. Janet Foley and Nicole Stephenson for University of California Davis for providing access to both samples and data for this study. In addition, the following people were essential in collection or preparing of samples or additional logistics for this study: Sal Chinnici, Robert Douglas, Desire Early, Dave Lancaster, Keith Hamm, Tamar Danufsky, Jeremy Rockweit, Bill McIver, Laura Wilkinson, and the many volunteers who skinned and prepared owl tissues at the California Academy of Sciences, Marcia Booth and Mike Filigenzi from CAHFS for preparing and running all the tissue samples.

\section{LITERATURE CITED}

Albert, C. A., L. K. Wilson, P. Mineau, S. Trudeau, and J. E. Elliott. 2010. Anticoagulant rodenticides in three owl species from western Canada, 1988-2003. Archives of Environmental Contamination and Toxicology 58:451-459. http://dx.doi. org/10.1007/s00244-009-9402-z

Battistone, C., and N. Clipperton. 2016. Status review of the Northern spotted owl (Strix occidentalis caurina) in California. State of California Department of Fish and Wildlife, Sacramento, California, USA.

Butsic, V., and J. C. Brenner. 2016. Cannabis (Cannabis sativa or C. indica) agriculture and the environment: a systematic, spatiallyexplicit survey and potential impacts. Environmental Research Letters 11:044023. http://dx.doi.org/10.1088/1748-9326/11/4/044023

Corva, D. 2014. Requiem for a CAMP: the life and death of a domestic U.S. drug war institution. International Journal of Drug Policy 25:71-80. http://dx.doi.org/10.1016/j.drugpo.2013.02.003

Diller, L. V., J. P. Dumbacher, R. P. Bosch, R. R. Bown, and R. Gutiérrez. 2014. Removing Barred Owls from local areas: techniques and feasibility. Wildlife Society Bulletin 38:211-216. http://dx.doi.org/10.1002/wsb.381

Diller, L. V., K. A. Hamm, D. A. Early, D. W. Lamphear, K. M. Dugger, C. B. Yackulic, C. J. Schwarz, P. C. Carlson, and T. L. McDonald. 2016. Demographic response of Northern Spotted Owls to Barred Owl removal. Journal of Wildlife Management 80:691-707. http://dx.doi.org/10.1002/jwmg.1046

Dugger, K. M., E. D. Forsman, A. B. Franklin, R. J. Davis, G. C. White, C. J. Schwarz, K. P. Burnham, J. D. Nichols, J. E. Hines, C. B. Yackulic, et al. 2016. The effects of habitat, climate, and Barred Owls on long-term demography of Northern Spotted Owls. Condor 118:57-116. http://dx.doi.org/10.1650/CONDOR-15-24.1 
Eason, C. T., E. C. Murphy, G. R. G. Wright, and E. B. Spurr. 2002. Assessment of risks of brodifacoum to non-target birds and mammals in New Zealand. Ecotoxicology 11:35-48. http://dx.doi. org/10.1023/A:1013793029831

Eason, C. T., and E. B. Spurr. 1995. Review of the toxicity and impacts of brodifacoum on non-target wildlife in New Zealand. New Zealand Journal of Zoology 22:371-379. http://dx.doi. org/10.1080/03014223.1995.9518055

Erickson, W., and D. Urban. 2004. Potential risks of nine rodenticides to birds and nontarget mammals: a comparative approach. United States Environmental Protection Agency, Office of Prevention, Pesticides and Toxic Substance, Washington, D. C., USA.

Gabriel, M. W., G. M. Wengert, J. M. Higley, S. Krogan, W. Sargent, and D. L. Clifford. 2013. Silent forests. Rodenticides on illegal marijuana crops harm wildlife. Wildlife Professional 7:46-50.

Gabriel, M. W., L. W. Woods, R. Poppenga, R. A. Sweitzer, C. Thompson, S. M. Matthews, J. M. Higley, S. M. Keller, K. Purcell, R. H. Barrett, et al. 2012. Anticoagulant rodenticides on our public and community lands: spatial distribution of exposure and poisoning of a rare forest carnivore. PLoS ONE 7:e40163. http:// dx.doi.org/10.1371/journal.pone.0040163

Gabriel, M. W., L. W. Woods, G. M. Wengert, N. Stephenson, J. M. Higley, C. Thompson, S. M. Matthews, R. A. Sweitzer, K. Purcell, R. H. Barrett, et al. 2015. Patterns of natural and humancaused mortality factors of a rare forest carnivore, the fisher (Pekania pennanti) in California. PLoS ONE 10:e0140640. http:// dx.doi.org/10.1371/journal.pone.0140640

Gianotti, A. G. S., J. Harrower, G. Baird, and S. Sepaniak. 2017. The quasi-legal challenge: assessing and governing the environmental impacts of cannabis cultivation in the North Coastal Basin of California. Land Use Policy 61:126-134. http:// dx.doi.org/10.1016/j.landusepol.2016.11.016

Gutiérrez, R. J., M. Cody, S. Courtney, and A. B. Franklin. 2007. The invasion of Barred Owls and its potential effect on the Spotted Owl: a conservation conundrum. Biological Invasions 9:181-196. http://dx.doi.org/10.1007/s10530-006-9025-5

Hamm, K. A., and L. V. Diller. 2009. Forest management effects on abundance of woodrats in northern California. Northwestern Naturalist 90:97-106. http://dx.doi.org/10.1898/NWN06-13.1

Long, J., L. Quinn-Davidson, and C. N. Skinner. 2014. Science synthesis to support socioecological resilience in the Sierra Nevada and southern Cascade range. General Technical Report no. PSWGTR 247. U.S. Forest Service Pacific Southwest Research Station, Albany, California, USA. https://doi.org/10.2737/PSW-GTR-247

Mendocino Redwood Company (MRC). 2004. Northern Spotted Owl conservation and management on Mendocino Redwood Company Forestlands. Mendocino Redwood Company Annual Northern Spotted Owl Report. 33.33. MRC, Ukiah, California

Murray, M. 2011. Anticoagulant rodenticide exposure and toxicosis in four species of birds of prey presented to a wildlife clinic in Massachusetts, 2006-2010. Journal of Zoo and Wildlife Medicine 42:88-97. http://dx.doi.org/10.1638/2010-0188.1
Polson, M. 2013. Land and law in marijuana country: clean capital, dirty money, and the drug war's rentier nexus. PoLAR: Political and Legal Anthropology Review 36:215-230. http://dx. doi.org/10.1111/plar.12023

Primus, T., G. Wright, and P. Fisher. 2005. Accidental discharge of brodifacoum baits in a tidal marine environment: a case study. Bulletin of Environmental Contamination and Toxicology 74:913-919. http://dx.doi.org/10.1007/s00128-005-0668-1

Rattner, B. A., K. E. Horak, R. S. Lazarus, K. M. Eisenreich, C. U. Meteyer, S. F. Volker, C. M. Campton, J. D. Eisemann, and J. J. Johnston. 2012. Assessment of toxicity and potential risk of the anticoagulant rodenticide diphacinone using Eastern ScreechOwls (Megascops asio). Ecotoxicology 21:832-846. http://dx.doi. org/10.1007/s10646-011-0844-5

Rueda, D., K. J. Campbell, P. Fisher, F. Cunninghame, J. B. Ponder, R. Moyse, and C. Shellswell. 2005. Biologically significant residual persistence of brodifacoum in reptiles following invasive rodent eradication, Galapagos Islands, Ecuador. Conservation Evidence 13:38.

Salim, H., H. M. Noor, D. Omar, N. H. Hamid, M. R. Z. Abidin, A. Kasim, C. S. Md Rawi, and A. H. Ahmad. 2014. Sub-lethal effects of the anticoagulant rodenticides bromadiolone and chlorophacinone on breeding performances of the Barn Owl (Tyto alba) in oil palm plantations. Slovak Raptor Journal 8:113-122. http://dx.doi.org/10.2478/srj-2014-0013

Stone, W. B., J. C. Okoniewski, and J. R. Stedelin. 1999. Poisoning of wildlife with anticoagulant rodenticides in New York. Journal of Wildlife Diseases 35:187-193. http://dx.doi.org/10.7589/0090-3558-35.2.187

Thomas, P. J., P. Mineau, R. F. Shore, L. Champoux, P. A. Martin, L. K. Wilson, G. Fitzgerald, and J. E. Elliott. 2011. Second generation anticoagulant rodenticides in predatory birds: probabilistic characterisation of toxic liver concentrations and implications for predatory bird populations in Canada. Environment International 37:914-920. http://dx.doi.org/10.1016/ j.envint.2011.03.010

Thompson, C., R. Sweitzer, M. Gabriel, K. Purcell, R. Barrett, and R. Poppenga. 2014. Impacts of rodenticide and insecticide toxicants from marijuana cultivation sites on fisher survival rates in the Sierra National Forest, California. Conservation Letters 7:91-102. http://dx.doi.org/10.1111/conl.12038

United States Fish and Wildlife Service. 2011. Revised recovery plan for the Northern Spotted Owl (Strix occidentalis caurina). U.S. Department of Interior, Portland, Oregon, USA.

Walker, C. H., R. Sibly, S. Hopkin, and D. B. Peakall. 2012. Principles of ecotoxicology. CRC, Boca Raton, Florida, USA.

Wang, I. J., J. C. Brenner, and V. Bustic. 2017. Cannabis, an emerging agricultural crop, leads to deforestation and fragmentation. Frontiers in Ecology and the Environment 15:495-501. http://dx.doi.org/10.1002/fee.1634

Weir, S. M., S. Yu, L. G. Talent, J. D. Maul, T. A. Anderson, and C. J. Salice. 2015. Improving reptile ecological risk assessment: oral and dermal toxicity of pesticides to a common lizard species (Sceloporus occidentalis). Environmental Toxicology and Chemistry 34:1778-1786. http://dx.doi.org/10.1002/etc.2975 
Weltje, L., P. Simpson, M. Gross, M. Crane, and J. R. Wheeler. 2013. Comparative acute and chronic sensitivity of fish and amphibians: a critical review of data. Environmental Toxicology and Chemistry 32:984-994. http://dx.doi.org/10.1002/etc.2149

Wiens, J. D., R. G. Anthony, and E. D. Forsman. 2014. Competitive interactions and resource partitioning between Northern Spotted Owls and Barred Owls in western Oregon. Wildlife Monographs 185:1-50. http://dx.doi.org/10.1002/wmon.1009

Wobeser, G. A. 2006. Essentials of disease in wild animals. Blackwell, Ames, Iowa, USA.

Wobeser, G. A. 2007. Investigation and Management of Disease in Wild Animals. Second edition. Springer-Verlag, Berlin, Germany. 